\title{
帝王切開における出産体験のとらえ方尺度の検討
}

\section{Development of a scale for perception of childbirth experience in regard to cesarean delivery}

\author{
吉 本 明 子 (Akiko YOSHIMOTO) *1 \\ 兒 玉 慎 平 (Shimpei KODAMA)*2 \\ 中 尾優子 (Yuko NAKAO)*2
}

抄 録

目的

本研究は，帝王切開における出産体験のとらえ方の構成項目を検討し，尺度の作成を行うことを目的 とした。

\section{対象と方法}

無記名自記式調査票を 4 施設にて平成 27 年 3 月 13 日から 8 月 31 日までの期間，緊急または予定帝王切 開後の裖婦に実施した。調査は留置式調査を用いた。

調査で使用するため，先行研究に基づき 26 項目から構成される尺度の原案を作成した。尺度原案の 項目分析後, 主因子法・プロマックス回転による探索的因子分析を行い, 因子構造を確認した。本尺度 の信頼性の検討として，Cronbachの $\alpha$ 係数とIT相関を確認した。また，妥当性の検討として，既知集 団妥当性と内容妥当性を確認した。

調査は，鹿児島大学医学部疫学・臨床研究等倫理委員会の承認を得た (受付番号 : 第327号)。

\section{結 果}

調査の結果，134名の有効回答を得た。

尺度原案における項目分析により，3項目を削除した。23項目を使用した因子分析の結果，3因子 15 項目が抽出された。因子は，第 1 因子 $<$ 出産の充足感 $>，$ 第 2 因子 $<$ 手術への適応 $>，$ 第 3 因子 $<$ 産み 方への受容 >と命名された。第 1 因子は 7 項目, 第 2 因子は 5 項目, 第 3 因子は 3 項目で構成された。

尺度の信頼性の検討として，Cronbachの $\alpha$ 係数は，全体で 0.823 ，各因子で $0.636 \sim 0.840$ となった。IT 相関では，全ての項目と尺度合計得点との間に有意な相関が示された $(\mathrm{p}<0.01)$ 。これょり，本尺度は 十分な信頼性を持つことが確認された。

妥当性において, 緊急帝王切開の平均得点が予定帝王切開より有意に低く $(\mathrm{p}<0.01)$, 先行研究と同 様の結果であったことから既知集団妥当性が確認された。また，助産学の専門家による調査票の自由記 述の見解と，抽出された因子がほぼ一致 (93\%) したことから，内容妥当性が確認された。

*1前鹿児島大学大学院保健学研究科 (Former Graduate School of Health Sciences, Kagoshima University)

*2 鹿児島大学医学部保健学科 (School of Health Sciences, Faculty of Medicine, Kagoshima University) 


\title{
結 論
}

本研究で新たに作成された帝王切開における出産体験のとらえ方尺度は，3つの因子から構成され， 信頼性と妥当性が確認された。本尺度は，帝王切開の裖婦の出産体験に対する認識を明らかにすること ができるといえる。今後，帝王切開の裖婦へのケアの改善に役立てるため，活用されることが期待でき る。

キーワード：帝王切開，出産体験，尺度，因子分析，信頼性，妥当性

\begin{abstract}
Purpose

The aim of this study was to consider items and develop a scale that measures mothers' perceptions of the childbirth experience in regard to cesarean delivery.
\end{abstract}

\section{Subjects and Methods}

An anonymous, self-administered questionnaire survey was conducted on puerperal patients in four hospitals who had undergone either emergency or planned cesarean delivery between March 13 and August 31, 2015. The survey was conducted using the placement method.

A draft scale composed of 26 items was designed for use in the questionnaire based on previous literature. After item analysis of the draft scale, the data were analyzed using principal factor analysis with promax rotation. The reliability of the scale was confirmed by Cronbach's $\alpha$ coefficient and item-total correlation, and the validity was confirmed by known-groups and content validity.

This study was approved by the Ethics Committee on Epidemiological Studies at the Kagoshima University Faculty of Medicine (Approval No. 327).

Results

Valid responses were collected from 134 mothers.

Three items were rejected based on item analysis of the draft scale. Factor analysis on the remaining 23 items identified 15 items and the following three factors: "feelings of fulfillment toward birth" (seven items), "adaptation to cesarean delivery" (five items), and "acceptance of my delivery method" (three items).

Regarding the reliability of the scale, Cronbach's $\alpha$ coefficient was 0.823 ( $0.636-0.840$ for subordinate factors). Item-total correlation indicated a significant correlation between all items and total score $(\mathrm{p}<0.01)$. Therefore, the reliability of this scale was confirmed for each factor.

Regarding the validity of the scale, the mean scores for emergency cesarean delivery were significantly lower than those for planned cesarean delivery $(\mathrm{p}<0.01)$, which confirmed the known-groups validity of the scale; this result was similar to those reported in previous studies. Content validity was established because the extracted factors were generally consistent with the opinions expressed by a midwifery expert in the free descriptions in the questionnaire. Conclusion

The newly developed scale used in this study, which was composed of three factors, showed good reliability and validity, which suggested that it was appropriate for measuring mothers' perceptions of the childbirth experience in regard to cesarean delivery. This scale can be used during birth reviews to improve care for puerperal patients who had a cesarean delivery.

Key words: cesarean delivery, childbirth experience, scale, factor analysis, reliability, validity

\section{I. 緒言}

現在の日本の帝王切開率は，平成 23 年度病院で $24.1 \%$, 診療所で $13.6 \%$ と(厚生労働省，2015a), 全体 で 5 人に 1 人が帝王切開で出産をしている。帝王切開分 娩の裖婦は予想と現実の不一致から分娩の失敗感や自 責の念が生じ, 自力で出産できなかったために母親と しての自信や自尊心の低下をまねき（森恵美，2011， p.391)，様々な心理的喪失から自己概念をおびやかす 否定的感情に陥ることがあるといわれている（近藤・ 堀内・内山・他, 1986)。また, 出産体験を肯定的 に認知している方が, 出産後の自尊感情と心の健康 は向上すると示されている（加納・島田・小松・他, 2004 ; 山口・平山, 2011)。以上より, 帝王切開で出 産をした裖婦であっても出産体験を肯定的に捉えるこ とは重要であり, 帝王切開体験の認知への心理的支援 
が必要であるといえる。

裖婦の出産体験を客観的に判断するための指標とし て, 出産体験尺度の開発が進められ，海外では 1970 年代より研究が開始されている。Samko, Schoenfeld （1975）は，出産に対する肯定的態度を測定する尺度 を作成した。15項目 1 因子で構成され，信頼性や妥当 性は確認されていない。これを元に Marut, Mercer （1979）は，緊急帝王切開袸婦も対象とした「The Perception of Birth Scale (POBS)」を開発した。29項 目より構成され，出産体験に対する裖婦の認識を測る 尺度となっている。しかし陣痛中のコントロールやリ ラクゼーションに関する項目が含まれており, 帝王切 開後の裖婦には一部適応していない。その後Mercer, et al.（1983）は，POBSの信頼性と妥当性を確認した。 Cranley, et al.（1983）は，対象を拡大するために POBSに手術前の手続きの認識を測定できるサブス ケールを追加し，予定帝王切開の裖婦にも使用できる 尺度を作成した。Fawcett, Knauth (1996) は, POBSに ロイ適応看護モデルを使用し，5因子 25 項目に改正し た。Gungor, Beji (2012) は, 出産方法で尺度を分類 し, 経胵分娩裖婦 43 項目, 帝王切開裖婦 42 項目から 構成される新たな尺度を開発した。これは裖婦の満足 度を測るうえで出産の際に受けたケアの認識に着目し ており，ケアや環境についての内容となっている。

一方, 日本では, 「出産経験のとらえ方尺度 (三枝, 1999)」,「出産体験自己評価尺度（常盤 - 今関, 2000)」,「変革につながるような出産経験尺度 TBEscale (三砂・嶋根・野口・他，2005）」,「出産体験尺度 CBE-scale (竹原・野口・嶋根・他, 2007)」が現在開 発されている。これらの尺度は, 再現性・内的妥当性 ・信頼性の全てを満たすものはまだ充分確立されてお らず，研究者によっても「自己評価」と「満足度」の概 念・構成要素に違いがみられている(末村・齋藤・戸 田・他, 2011)。また, 主な対象が経腔分娩となって おり, 帝王切開のみに焦点をあてたものは存在しな い。項目にはいきみや陣痛に関する内容が含まれてお り, 帝王切開の裖婦には答えにくく, 心理を適切に捉 えられるとは言いがたい。海外では日本と異なり, 経 腟分娩と帝王切開の双方に使用できる尺度が開発され ているが，出産には文化的な認識の違いがあるといわ れており（藤原，2006）, 日本独自の尺度を開発する ことで, 日本での出産体験を客観的に評価することが でき, 帝王切開の裖婦に適切な支援を提供できると考 えた。
本研究では，帝王切開における出産体験のとらえ方 の構成項目を検討し, 尺度の作成と信頼性と妥当性の 検討を目的とする。

\section{II. 対象}

帝王切開を実施している同市内の4施設 (総合病院 3 施設, 産婦人科病院 1 施設) から研究参加への承諾が 得られ, 緊急帝王切開と予定帝王切開の双方を対象と した。出血量が多い, 児がNICUに入院中などの背景 がある方は, 心身の状態が不安定であると判断し, 調 査協力が悪影響を及ぼすため, 死産の裖婦とともに除 外対象とした。

\section{III. 研 究方法}

\section{1. 質問項目の作成}

\section{1 ) 質問項目の検討}

帝王切開における出産体験のとらえ方に関する項目 は, 帝王切開に関する質的研究の国内の先行文献 (堀 内 - 近藤 - 石井 - 他, 1987 ; 今崎, 2006 ; 國崎 - 渡辺 - 平添 - 他, 2011 ; 壬生 - 諸原 - 奈良, 2002 ; 見目 $\cdot$ 東野, 2007 ; 中間 - 山内, 2007 ; 岡田 - 白井, 1996 ; 大林 - 石村, 2010 ; 鈴木 - 長谷川 - 中村 - 他, 2011 ; 渡辺・ 三浦 - 城, 2008 ; 横手 - 永田 · 宮里, 2006) 上 り抜粋し, 検討した。先行文献 11 件中, 産後 7 日以内 に調査を実施していたのは8件であった。母親が感じ ていると思われたすべての項目を文献より抜粋し，そ の内容の相違点・共通点に着目し, 共通点に関しては 研究者により抽象化を進め, 項目として列挙した。そ の際, 出産体験を評価する場合には, 分娩時のケアに 関る項目が尺度に含まれることは不適切であるといわ れている (竹原・野口・嶋根・他, 2007) ため, 本尺 度では帝王切開時の産婦自身の体験や思いをどのよう に捉えているかに焦点を当てた項目を使用した。ま た, 回答が同意に偏る黙従傾向を防ぐために, 9項目 の逆転項目を使用し, 項目は簡単な言葉で理解しやす い内容となるょうに努めた。

この過程において助産学の専門家によるスーパーバ イズを受け，26項目から構成される尺度の原案を作 成した。

\section{2 ) 尺度案の妥当性の検討}

作成した項目案の内容妥当性を確認するために, 助 産学の専門家 5 名によりスーパーバイズを受けた。用 
語の理解のしやすさ，回答のしやすさ，心理的・時間 的な負担などの指摘を受け，表現の修正を行った。

表面的妥当性を確認するために, 出産経験者 9 名に プレテストを実施した。全員が全質問項目に回答して おり，回答可能な内容であることを確認した。質問紙 については，言葉の表現の分かりやすさ，回答の負担 感, 項目内容の適切さについて意見を求め, 指摘内容 については修正を行い, 再度助産学の専門家による スーパーバイズを受け，質問項目を完成させた。

3 ) 回答方法

帝王切開における出産体験のとらえ方に関する 26 項目の回答形式は, リッカート法を使用した。5件法 (1：とてもそう思わない〜 5：とてもそう思う)で測

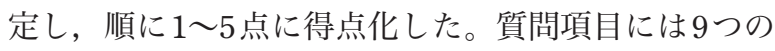
逆転項目が含まれるため，解釈を「1：とてもそう思 う」から「5：とてもそう思わない」とした。逆転項目 の採点処理を実施したのちに総得点, 下位尺度得点と もに単純加算し，得点が高いほうが帝王切開における 出産体験のとらえ方が肯定的であることを示すものと した。

\section{2. データ収集}

\section{1 ) 調査方法}

平成 27 年 3 月 13 日〜 8 月 31 日の期間，すべての対象 者に文書と口頭にて研究の趣旨と協力の依頼について 説明を行った。対象者の選別については, 説明を研究 者が行った場合, 病棟の責任者から情報を得て, 適任 者に実施した。施設の研究協力者が行った場合，対象 の基準に基づき選択し実施した。説明は裖婦の疲労回 復後に個別に行った。説明文書には, 研究の背景, 目 的, 方法, 予測される結果, 本研究への参加は強制さ れないこと, 同意しない場合であってもいかなる不利 益も受けないこと, 個人情報が保護されることを記載 した。研究参加に同意が得られた方に無記名の自記式 調査票を配布した。回収方法は対象者自身で施設に設 置してある回収箱へ投函する留置調査法を用いた。対 象者が調查票に記入する時期については，手術による 負担を考慮し，退院までの期間ならいつでもよいこと を伝えた。対象者自身の回収箱への投函をもつて, 研 究参加への同意とした。

\section{2 ) 調査内容}

調査内容は, 対象者の属性 (年齢・出産経験), 今 回の帝王切開に関する情報 (出産方法・分娩週数・回 答時の産後日数・児の出生時体重・帝王切開の可能性
の予測 - 児の出生時状態), 帝王切開における出産体 験のとら方に関する 26 項目であった。また，今回 の帝王切開でのお産についてどう感じたかを問う自由 記述欄を設けた。

\section{3. 分析方法}

統計解析には, 統計解析用ソフト SPSS ver.23を使 用した。

\section{1 ) 項目分析}

帝王切開における出産体験のとらえ方に関する 26 項目について, 項目分析を行った。平均值，標準偏 差, 天井・床効果について確認し, 項目の除外を検討 した。なお，逆転項目の記載については（R)を付記 する。

\section{2 ) 因子分析}

質問項目の選定と構造を明らかにするため，探索的 因子分析 (主因子法・プロマックス回転)を実施した。 項目選択基準として，(1)共通性 0.16 以上，(2)因子負荷 量 0.40 以上, (3) 2 因子以上に重複して高い負荷量 (0.40 以上) がみられない項目であることとした。抽 出された因子に基づき，構成概念の命名を行った。そ の後各因子の相関を確認し, 下位尺度得点と尺度全体 得点を算出した。下位尺度得点間の相関を Spearman の順位相関係数によって確認した。

\section{3 ) 信頼性の検討}

内容の一貫性と内的整合性の検証として，尺度全 体，および各因子のCronbachの $\alpha$ 係数を算出した。IT 相関の分析を行い, Spearmanの順位相関係数によっ て確認した。

\section{4 ) 妥当性の検討}

先行研究 (上條・松原 - 松本 - 他, 1999 ; 岡田 - 白 井, 1996 ; 大林・石村, 2010) では, 予定帝王切開の 裖婦と比較し, 緊急帝王切開の裖婦の方が出産体験に 関して否定的に捉えていることが報告されている。こ れより緊急帝王切開裖婦の方が尺度得点は低いと仮説 をたて，既知集団妥当性を検討した。緊急帝王切開と 予定帝王切開に分け, 下位尺度得点と尺度合計得点に ついて正規性を確認したのち, Mann-WhitneyのU検 定と検定を行った。

また, 内容妥当性の検討として, 有効回答のうち調 査票の自由記述に記載のあった 81 名の回答内容と本 尺度の構成項目の関連をみるために, 研究に関わって いない助産学の専門家に意見を求めた。 


\section{4. 倫理的配慮}

本研究への協力は自由意思によるものとし, 協力を 拒否しても不利益はないことを保証した。調査票は無 記名とし，調査票の投函をもつて同意を得たものとし た。なお, 本研究は鹿児島大学医学部疫学・臨床研究 等倫理委員会の承認を受け, 承認後調査を開始した (受付番号 : 第327号)。

\section{IV. 結 果}

調査票を配布した 166 名のうち 149 名（回収率： $89.8 \%)$ から回答が得られ，欠損值のみられない 134 名 （有効回答率： 89.9\%）のデー夕を，尺度を作成するた めの分析対象とした。施設の内訳は $\mathrm{A}$ 病院 23 名・B病 院 33 名 $\cdot \mathrm{C}$ 病院 50 名 (総合病院), D病院 28 名 (産婦 人科病院)である。

\section{1．対象者の属性 (表1)}

年齢構成は，35歳以上が55名 $(41.0 \%)$ と最も多 かった。全体の平均年齢は, 33.1 4.9 歳であった。初 経産別割合は，同程度の割合であった。経産婦の出産 経験数は，1経産が 48 名 $(35.8 \%)$ と最も多く，次いで 2 経産 13 名 $(9.7 \%) ， 3$ 経産 3 名 $(2.2 \%) ， 5$ 経産 1 名 (0.7\%) であった。帝王切開の既往がある裖婦は 46 名 (34.3\%) であった。出産方法は, 緊急帝王切開 70 名 (52.2\%)，予定帝王切開64名 (47.8\%) と同程度の割合 であった。分娩週数は, 正期産が 94 名で 7 割を占め た。平均分婏週数は $36.7 \pm 2.8$ 週であった。回答時の 平均産後日数は $4.68 \pm 2.42$ 日であった。出生した児の 人数は双胎 14 件を含め 148 名であった。児の出生時体 重は，2500g 以上が 84 名 $(56.8 \%) ， 2500 \mathrm{~g}$ 未満が 61 名 (41.2\%) であり，低出生体重児が多くみられた。児の 平均出生時体重は2499.6 $2608.9 \mathrm{~g}$ であった。

帝王切開可能性について，妊娠中に自身が帝王切開 になる可能性があると思っていた裖婦は105名 (78.4\%) であり多くの裖婦が予想をしていた。児の出生時状態 は，非常に元気 56 名 $(41.8 \%)$, 元気 62 名 (46.3\%) と8 割以上の裖婦が元気であったと答えていた。

\section{2. 帝王切開における出産体験のとらえ方尺度の構成 項目の検討}

\section{1 ) 項目分析 (表2)}

天井効果が 7 項目，床効果が 1 項目，合わせて 8 項 目にみられた。回答範囲は5 段階だが，8項目中 5 項 $\mathrm{n}=134$

\begin{tabular}{|c|c|c|}
\hline 属性 & $\mathrm{n}$ & $\%$ \\
\hline \multicolumn{3}{|l|}{ 年齢 } \\
\hline $20 \sim 24$ 歳 & 5 & 3.7 \\
\hline $25 \sim 29$ 歳 & 25 & 18.7 \\
\hline $30 \sim 34$ 歳 & 49 & 36.6 \\
\hline 35 歳以上 & 55 & 41.0 \\
\hline \multicolumn{3}{|l|}{ 初経産別割合 } \\
\hline 初産婦 & 69 & 51.5 \\
\hline 経産婦 & 65 & 48.5 \\
\hline \multicolumn{3}{|l|}{ 帝王切開既往 } \\
\hline あり & 46 & 34.3 \\
\hline \multicolumn{3}{|l|}{ 出産方法 } \\
\hline 緊急帝王切開 & 70 & 52.2 \\
\hline 予定帝王切開 & 64 & 47.8 \\
\hline \multicolumn{3}{|l|}{ 分姺週数 } \\
\hline 正期産 & 94 & 70.1 \\
\hline 早産 & 40 & 29.9 \\
\hline \multicolumn{3}{|l|}{ 児の出生時体重 } \\
\hline \multicolumn{3}{|l|}{ （双胎 14 例含む $n=148$ ) } \\
\hline $2500 \mathrm{~g}$ 以上 & 84 & 56.8 \\
\hline $2500 \mathrm{~g}$ 未満 & 61 & 41.2 \\
\hline 無回答 & 3 & 2.0 \\
\hline \multicolumn{3}{|l|}{ 帝王切開可能性 } \\
\hline あると思っていた & 105 & 78.4 \\
\hline 思っていなかった & 28 & 20.9 \\
\hline どちらでもない & 1 & 0.7 \\
\hline \multicolumn{3}{|l|}{ 児の出生時状態 } \\
\hline 非常に元気 & 56 & 41.8 \\
\hline 元気 & 62 & 46.3 \\
\hline ぞちらでもない & 4 & 3.0 \\
\hline やや元気そうではない & 2 & 1.5 \\
\hline 全く元気がない & 1 & 0.7 \\
\hline 分からない & 5 & 3.7 \\
\hline 無回答 & 4 & 3.0 \\
\hline
\end{tabular}

目は4段階以上の幅広い回答範囲をとつていた。これ らは標準偏差も比較的大きく，ばらつきがみられると 判断できるため, 残すことが妥当と判断した。8項目 中，回答範囲が3段階（3〜5）となるものに「出産を経 験できてょかった」,「子どもの誕生に感激した」,「子 どもに会えてうれしい」の3項目がみられた。この 3 項目の標準偏差は小さく, 分布に偏りがあると判断 し，分析から除くこととした。

2 ) 因子分析 (表3)

項目分析により不適切とされた 3 項目を除く 23 項目 を使用し，探索的因子分析を行った。主因子法，回転 なしの因子分析を行い，共通性を検討したが，削除す べき項目はなかった。因子のスクリープロットの形 状, 固有值の変化, 解釈の可能性から 3 因子構造が妥 当であると考元，因子数を決定した。

23 項目を使用し，因子数を 3 に指定した主因子法・ プロマックス回転による因子分析を行った。項目選択 基準に基づき，基準を満たさない項目を削除しつつ， 


\begin{tabular}{|c|c|c|c|c|}
\hline 項目 & 最小值 & 最大值 & 平均值 & 標準偏差 \\
\hline 出産を経験できてよかつた ${ }^{+}$ & 3 & 5 & 4.63 & 0.556 \\
\hline 産み方にこだわることはない & 1 & 5 & 4.10 & 0.866 \\
\hline イメージ通りのお産だった & 1 & 5 & 2.84 & 1.149 \\
\hline 普通分婏がしたかった (R) & 1 & 5 & 2.53 & 0.994 \\
\hline 子どもの誕生に感激した ${ }^{+}$ & 3 & 5 & 4.87 & 0.403 \\
\hline 納得がいかなかった (R) & 1 & 5 & 4.16 & 0.839 \\
\hline 重圧から解放された & 1 & 5 & 3.31 & 1.209 \\
\hline 無事終えてほっとした ${ }^{+}$ & 1 & 5 & 4.66 & 0.660 \\
\hline $\begin{array}{l}\text { 帝王切開になったことは仕方 } \\
\text { がない }+{ }^{+}\end{array}$ & 1 & 5 & 4.39 & 0.794 \\
\hline 手術がこわかった (R) + & 1 & 5 & 2.13 & 1.147 \\
\hline 女性にうまれてよかった + & 2 & 5 & 4.30 & 0.756 \\
\hline $\begin{array}{l}\text { 無事出産を終えてうれしくて } \\
\text { たまらない }{ }^{+}\end{array}$ & 1 & 5 & 4.49 & 0.712 \\
\hline $\begin{array}{l}\text { なにが起きているか分からな } \\
\text { かった }(\mathrm{R})\end{array}$ & 1 & 5 & 3.33 & 1.194 \\
\hline 産んだ実感がある & 2 & 5 & 3.98 & 0.845 \\
\hline 産みきれなかった (R) & 1 & 5 & 3.93 & 0.978 \\
\hline $\begin{array}{l}\text { 自分の力ではどうにもできな } \\
\text { い(R) }\end{array}$ & 1 & 5 & 2.22 & 1.031 \\
\hline やることはやった & 1 & 5 & 4.11 & 0.847 \\
\hline 自信がついた & 1 & 5 & 3.35 & 0.920 \\
\hline 孤独だった (R) & 1 & 5 & 3.96 & 1.010 \\
\hline 達成感をもてた & 1 & 5 & 3.70 & 0.934 \\
\hline $\begin{array}{l}\text { もう少し項㖘れはよよかつた } \\
\text { (R) }\end{array}$ & 1 & 5 & 3.60 & 1.077 \\
\hline 思っていたより楽だった & 1 & 5 & 2.24 & 1.171 \\
\hline 想像以上の痛みだった (R) & 1 & 5 & 2.52 & 1.200 \\
\hline $\begin{array}{l}\text { 帝王切開という良い選択がで } \\
\text { きた }\end{array}$ & 1 & 5 & 3.45 & 0.872 \\
\hline 子どもに会えてうれしい+ & 3 & 5 & 4.93 & 0.280 \\
\hline お産に満足できた & 1 & 5 & 4.17 & 0.827 \\
\hline
\end{tabular}

$\mathrm{n}=134$

\begin{tabular}{|c|c|c|c|c|}
\hline & I & II & III & IT相関 \\
\hline \multicolumn{5}{|l|}{ 第1因子 $<$ 出産の充足感 $>\alpha=.840$} \\
\hline $\begin{array}{l}\text { 無事出産を終えてうれしくてたま } \\
\text { らない }\end{array}$ & .89 & .01 & -.30 & $.521^{*}$ \\
\hline やることはやった & .78 & -.28 & .12 & $.541^{* *}$ \\
\hline 無事終えてほっとした & .76 & -.11 & -.13 & $.470 * *$ \\
\hline 達成感をもてた & .67 & .00 & .17 & $.719^{* *}$ \\
\hline 自信がついた & .62 & .10 & -.07 & $.549 * *$ \\
\hline お産に満足できた & .58 & .25 & .04 & $.708^{*}$ \\
\hline & .50 & .02 & .01 & \\
\hline
\end{tabular}

\begin{tabular}{|c|c|c|c|c|}
\hline つていたより楽だった & -.07 & .74 & -.16 & $.367^{* *}$ \\
\hline 像以上の痛みだった $(\mathrm{R})$ & -.05 & .51 & -.07 & $.416^{* *}$ \\
\hline 分の力ではどうにもできない & -.10 & .47 & .06 & .349 \\
\hline $\begin{array}{l}\text { :が起きているか分からなかつ } \\
\text { R) }\end{array}$ & .09 & .44 & .01 & .474 \\
\hline ふいかなかった（ & .20 & .42 & .22 & $.627 * *$ \\
\hline
\end{tabular}

\section{第 3 因子 $<$ 産み方の受容 $>\alpha=.644$}

\begin{tabular}{l|r|r|r|l} 
産んだ実感がある & .12 & -.10 & $\mathbf{. 7 0}$ & $.580^{* *}$ \\
産み方にこだわることはない & -.25 & -.06 & $\mathbf{. 6 7}$ & $.293^{*}$ \\
産みきれなかった $(\mathrm{R})$ & .24 & .17 & $\mathbf{. 4 7}$ & $.717^{* *}$
\end{tabular}

\begin{tabular}{rccc}
\hline 下位尺度得点相関 & I & II & III \\
I & - & $.307^{* *}$ & $.544^{* *}$ \\
II & & - & $.302^{* *}$ \\
III & & \multicolumn{2}{c}{-} \\
\hline
\end{tabular}

因子抽出法：主因子法回転法：Kaiserの正規化を伴う プロマックス法

Spearmanの順位相関係数 $\quad * \mathrm{p}<.01 \quad * * \mathrm{p}<.001$

分析を 4 回繰り返した。最終的に因子分析では「イ メージ通りの拉産だった」普通分娩がしたかった (R)」「重圧から解放された」帝王切開になったこと は仕方がない」「手術がこわかった (R)」「女性にうま 机てよかった」「孤独だった（R)」「帝王切開という良 い選択ができた」の，8項目が削除された。

以上の結果，最終的に 3 因子 15 項目を採用した。因 子抽出後の因子負荷量は $0.42 \sim 0.89$ であり, 因子的妥 当性を検討するために十分な值であると判断した。

3 ) 因子構造

抽出された 3 因子の，各項目の内容を解釈した。

第 1 因子は 7 項目で作成され, 出産を終えた喜び, 安堵感，満足感，達成感に満たされている状況を示し ていると考えられ，＜出産の充足感＞と命名した。

第 2 因子は 5 項目で作成され，帝王切開という手術 が許容範囲内の体験であった心の余裕と, 経過が理解 できたことを表しているといえるため，＜手術への適 応〉と命名した。

第 3 因子は 3 項目で作成され，帝王切開でも十分に 出産の実感を持っており, 出産方法に執着しない肯定 的な受け入れが表れていることから，＜産み方の受 容〉と命名した。

\section{3. 信頼性の検討}

\section{1 ) Cronbach $\propto \alpha$ 係数 (表 3 )}

Cronbachの $\alpha$ 係数は, 尺度全体では 0.823 を示した。 各因子では，第 1 因子 $<$ 出産の充足感 $>$ が 0.840 , 第 2 因子 $<$ 手術への適応 $>$ が 0.636 , 第 3 因子 $<$ 産み方の 受容>が 0.644 を示した。

\section{2 ) IT相関 (表3)}

IT相関において，すべての項目と尺度合計得点と の間に $0.293 \sim 0.719$ の相関がみられ，有意な相関係数 が示された $(\mathrm{p}<.01)$ 。

3 ) 尺度と下位尺度得点 (表 3 )

3 つの下位尺度の相関を求めた結果，有意な正の相 関 (0.302 0.544) がみられた $(\mathrm{p}<.001)$ 。信頼性が確 認され，下位尺度間に正の相関があることより，15 


\section{表4 既知集団妥当性}

\begin{tabular}{|c|c|c|c|c|c|}
\hline & \multicolumn{2}{|c|}{$\begin{array}{c}\text { 緊急帝王切開 } \\
(n=70)\end{array}$} & \multicolumn{2}{|c|}{$\begin{array}{c}\text { 予定帝王切開 } \\
(n=64)\end{array}$} & \multirow[t]{2}{*}{ p值 } \\
\hline & 平均值 & 中央值 & 平均值 & 中央值 & \\
\hline 尺度合計得点 ${ }^{a}$ & $51.4 \pm 7.0$ & 52 & $58.0 \pm 6.9$ & 59 & $.000 * *$ \\
\hline$<$ 出産の充足感 $>$ 得点 ${ }^{\mathbf{a}}$ & $26.7 \pm 4.7$ & 27 & $29.7 \pm 3.3$ & 30 & $.000 * *$ \\
\hline <手術への適応 $>$ 得点 ${ }^{b}$ & $13.3 \pm 3.0$ & 13 & $15.8 \pm 3.6$ & 16 & $.000 * *$ \\
\hline$<$ 産み方の受容 $>$ 得点 $^{\mathrm{a}}$ & $11.5 \pm 1.9$ & 12 & $12.6 \pm 2.1$ & 13 & $.001^{*}$ \\
\hline
\end{tabular}

項目の得点を加算し，尺度得点（15～75点）として算 出可能であると判断した。

\section{4. 妥当性の検討}

1 ) 既知集団妥当性 (表4)

緊急帝王切開と予定帝王切開に分け，下位尺度と尺 度合計の得点について正規性を確認したところ，両者 の<手術への適応 $>$ 得点と, 予定帝王切開の尺度合計 得点において正規性がみられた。そのため，緊急帝王 切開と予定帝王切開の 2 群を比較するにあたり，〈手 術への適応＞得点にはt検定，その他の下位尺度と尺 度合計得点にはMann-WhitneyのU検定を行いた。そ の結果，すべての得点において，緊急帝王切開の得点 が低く，予定帝王切開との間に有意な差がみられた $(\mathrm{p}<.01)$ 。緊急帝王切開の尺度全体得点が低いという 仮説が証明され，本尺度が既知集団妥当性を有するこ とが確認された。

\section{2 ) 内容妥当性}

研究に関わらず，質問項目の作成に携わっていない 助産学の専門家に, 今回の調査票の自由記述に記載の あった 81 名の回答内容について意見を求め, 本尺度の 項目内容と比較した。因子分析後に抽出された因子や 項目が出産体験のとらえ方を適切に表しているかにつ いて，専門家の見解と本尺度の構成項目15項目中14項 目が一致しており，93\%の割合で整合性を認めた。

\section{V. 考察}

\section{1. 尺度の因子構造}

1 ）<出産の充足感>

<出産の充足感 >とは，これまでの経過の中で「や ることはやった」,「もう少し頑張ればよかった $(\mathrm{R}) 」$ と認識でき，産声を聞いて「無事出産を終えてうれし くてたまらない」,「無事終えてほっとした」と感じる。 痛みや不安を乗り越えて出産した自身への「達成感を もてた」「自信がついた」ことを通して満たされてお
り,「お産に満足できた」という充足感を表している。 満足感や達成感については<幸福因子 (竹原・野口 ・嶋根・他, 2007) >や, <満足 (達成・喜び・感 動) $>，<人$ 間的成長 $>$ (三枝，1999）など，既存の 尺度でも抽出されている。

自尊感情を高めて育児に臨むために, 出産体験を肯 定的に捉えることは重要であるといわれている（加納

- 島田・小松・他，2004; 山口・平山，2011）。否定 的感情を抱きやすい帝王切開での分娩であるからこそ 充足感を得ることは必要であり，不安や痛みを乗り越 えた経験の認識はこれからの育児に対する自信につな がることが期待できる。帝王切開であっても出産とい う出来事から得られる心理的効果を測るうえで，この 因子は妥当であるといえる。

\section{2 ）＜手術への適応>}

〈手術への適応＞とは，出産ではあるが手術でもあ るため，身構えて緊張していたが「思っていたより楽

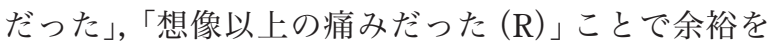
持つことができる，手術でも「自分の力ではどうにも できない $(\mathrm{R}) 」 と$ 感じ，経過を理解することで「なに が起きているか分からなかった $(\mathrm{R}) 」$,「納得がいかな かった $(\mathrm{R}) 」$ 出産だといえる。手術での経過に対し適 応していることを表している。

既存の尺度には，<自分なりにうまくできた(常盤 ・今関，2000) >や，〈ボディセンス >，〈あるがま ま>（竹原・野口・嶋根・他, 2007) という因子があ るが，これらはいきみや呼吸法がうまくできたか，自 分をコントロールできたかという項目で構成されてお り, 帝王切開の裖婦には回答が難しい。<出産に対す る否定 (三枝，1999)>という因子については痛みや 所要時間が想像以上で自分の弱さを知った体験で あったことを示している。これより, 帝王切開者にも いえる内容，かつ経過の受け入れに関して心が適応・ 不適応であるという因子は抽出されていない。新たに 発見された因子であり, 本研究で帝王切開の裖婦のみ に調査を行った結果，明らかになったものといえる。 
3 ）＜産み方の受容 $>$

＜産み方の受容＞とは, 帝王切開でも私が「産んだ 実感がある」と感じ，十分に攧張ることができ「産み きれなかった $(\mathrm{R}) 」$, , 大事なことは方法ではなく妊娠 し出産までたどり着き，母子共に無事であることであ るために「産み方にこだわることはない」と認識して いることを表している。先行研究において, 帝王切開 を受容し肯定的感情へ転換するためには，出産の安全 性が重要視されていることが報告されている(今崎, 2006 ; 上條・松原・松本 - 他, 1999 ; 竹内, 2014)。 子どもを最優先に考元，無事が一番であるという安全 面への母親の思いが, 出産方法にこだわらない要因と なっていることが考えられる。一方，経腟分婏を希望 していたことは，帝王切開への否定的感情につながる といわれている(岡田・白井, 1996 ; 上條・松原・松 本・他，1999；今崎，2006)。本因子では母親の出産 観も読み解くことができるといえる。

既存の尺度では，主に経胵分婏を対象とし，帝王切 開を想定した項目作成がされていないと考えられるた め，本因子のように産み方の受容のみに関する因子は みられなかった。また, 本研究の<出産の充足 感 $>$ と<産み方の受容 $>$ の位尺度相関は高く (0.544), 無事に出産を終えた安心感という点で類似 の概念を示している。しかし，前者は子どもを産んだ 経験を通して感じたこと, 後者は帝王切開という手段 を通して感じたこととして，区別して捉えられると考 える。以上より, 帝王切開のとらえ方を把握するにあ たって，本因子は妥当であるといえる。

\section{2. 尺度の信頼性}

信頼性について，尺度の安定性を確かめるため再テ スト法を実施することが望まれている。その際，テス 卜間に対象者の特性が変化していないこと, 結果に記 憶の影響がないことが前提となるが（村上，2006, p.35), 出産体験は時間が経つと変化するといわれて おり（我部山・池田・宮中・他，1996）, 裖婦の負担 も考慮し, 本研究では再テスト法の実施は適切ではな いと考えた。そのため，信頼性の検討としてCronbachの $\alpha$ 係数とIT相関を使用した。

本研究で作成した尺度のCronbachの $\alpha$ 係数は, 各因 子では $0.636 \sim 0.840$, 尺度全体では 0.823 を示した。 Cronbachの $\alpha$ 係数は 0.6 以上であれば高い，0.8以上で あれば非常に高いといえるため(松井，2010，p.125)， 本研究の結果は十分な信頼性を持つといえる。
また，内的整合性の高い尺度を作成するためには， 各項目と尺度合計得点の相関係数を計算し, 相関を確 認し項目分析をする方法が推奨される（村上，2006， p.71)。本研究ではIT相関において，すべての項目と 尺度合計得点との間に有意な相関が示された $(\mathrm{p}<$ .01）。以上より，尺度を構成する 15 項目は十分な内的 整合性があるといえる。

\section{3. 尺度の妥当性}

帝王切開に特化した出産体験の尺度はなく, 既存の 尺度との比較によって基準関連妥当性を検討すること は困難である。本研究では妥当性の検討として, 既知 集団妥当性と内容妥当性, 表面妥当性から評価し, 妥 当性を高められるよう努めた。

緊急帝王切開は予定帝王切開に比較し, 出産体験を 否定的に捉えており，尺度全体得点は低いと仮説をた て検証した結果, 本研究では予定帝王切開と比較して 緊急帝王切開の裖婦の得点が有意に低く, 出産体験に 関して否定的なとらえ方をしていることが証明された $(\mathrm{p}<.01)$ 。先行研究との結果の整合性が確認され, 本 尺度が測定しているものが帝王切開の特徵を捉えてい るといえる。

項目内容について，質問項目を作成するプロセスに おいて専門家を交えた検討を行い，因子分析後に抽出 された因子について専門家の見解と比較するなどの過 程を経たことより, 高い内容妥当性が得られたと考え る。

\section{4. 帝王切開における出産体験のとらえ方尺度の意義 と活用可能性}

健やか親子 21 (第2次) での「妊娠・出産について満 足している者の割合の増加」の課題では, 満足度を高 めるためには妊娠・出産の満足度の客観的評価方法の 開発が必要であるとされている(厚生労働省, 2015b)。 経腟分娩と同じ指標ではなく, 帝王切開での出産を肯 定的に捉えているか否かを客観的に把握するための本 尺度を開発していくことは意義があるといえる。

出産体験の自己評価は母親意識の発達を促す要素の 一つであり, 産後うつ傾向の予測要因の一つであるこ とが報告されている（常盤・國清，2006）。出産体験 を共に振り返り意味づけを行うことは重要であり，本 尺度得点が低い裖婦は, 出産体験を否定的に捉えてい るため, 精神的介入や支援が必要であるといえる。 バースレビュー時に活用することで，ケアの必要性に 
ついて簡便なスクリーニングを行うことができる。さ らに，経験年数などによりアセスメントカの異なる医 療者間で，同じ視点でリスクを測ることができる。

今後, 帝王切開となった女性がより良い出産体験で あったと捉えることができるように，バースレ ビューの段階で本尺度が活用され，ケアの改善に役立 てられることが期待される。

\section{5. 本研究の限界と今後の課題}

本研究にはいくつかの限界がある。一つ目には，再 テストによる信頼性の評価をしていないことがあげら れる。本尺度の場合, 同一対象への再テスト法は適切 ではないため，対象を変えた集団で安定性を確認する ことが必要であるといえる。また，回答時の産後日数 を限定した調査も必要である。二つ目には, 対象地域 の偏りがあげられる。今後は対象地域を拡大し, 対象 者数も増加したうえで調査を実施する必要がある。三 つ目には, 反復帝王切開など背景を踏まえた比較がで きていないため, 今後の課題として挙げられる。しか し，今回は，規模の異なる4施設において調査を実施 し，幅広い対象に調査を行うことができ，帝王切開の 属性の一般化に近い結果を得ることができた点は評価 できる。

\section{VI. 結 論}

帝王切開における出産体験のとらえ方尺度の構成項 目の検討をし, 尺度作成を試みた。結果, 3 因子 15 項 目が抽出され, 第 1 因子<出産の充足感 $>$, 第 2 因 子 $<$ 手術への適応 $>$, 第 3 因子 $<$ 産み方への受容 $>$ と 命名された。本尺度は十分な信頼性と妥当性を有する ことが確認された。

\section{謝 辞}

本研究を行うにあたり, ご協力いただきましたお母 さま方，ご理解をいただきご協力くださいました研究 施設の職員の皆さまに心より感謝いたします。

\section{文 献}

Cranley, M. S., Hedahl, K. J., \& Pegg, S. H. (1983). Women's perception of vaginal and cesarean deliveries. Nursing Research, 32(1), 10-15.

Fawcett, J. \& Knauth, D. (1996). The factor structure of the perception of birth scale. Nursing Research, 45(2), 83-
86.

藤原ゆかり (2006)。異文化圈からの人々の出産に対する 助産ケアの現状一文化を考慮したケアの実現に向け て一. 日本助産学会誌, 20(1), 48-59.

Gungor, I. \& Beji, N. K. (2012). Development and psychometric testing of the scales for measuring maternal satisfaction in normal and caesarean birth. Midwifery, 28(3), 348-357.

堀内成子, 近藤潤子, 石井ひとみ, 福地彰子 (1987)。帝 王切開分婏における母子相互作用に関する研究 (第 2 報) 一帝王切開分娩産婦の心理的喪失体験の分析一. 周産期医学, 17(3), 429-435.

今崎裕子 (2006)。緊急帝王切開を体験した女性の出産後 約 1 年半までの出産に関する気持ち. 日本助産学会 誌, 20(1), 79-88.

我部山キヨ子, 池田浩子, 宮中文子, 堀内寛子, 伊藤三紀 子, 多田秀子, 他 (1996). 出産体験に関する研究 (第 1 報) 一出産体験の評価の経日的変化一. 母性衛 生, 37(1), 16-24.

上條陽子, 松原美和, 松本あつ子, 湯本敦子, 飯沼博朗 (1999)。帝王切開分婏褛婦の受けとめと満足感。母 性衛生, 40(1), 68-71.

加納尚美, 島田智織, 小松美穂子, 永瀬つや子, 楠見由里 子, 佐々木美智子, 他 (2004). 茨城県における出産 の実態と満足度に関する研究. 茨城県立医療大学紀 要, $9,1-10$.

近藤潤子, 堀内成子, 内山芳子, 押尾祥子, 堀川彰子 (1986)。帝王切開分婏における母子相互作用に関す る研究 (第 1 報) 一帝王切開分婏産婦の心理に関する 文献的考察一. 周産期医学, 16(4), 599-609.

厚生労働省 (2015a)，2-10 医療機関におけ子分娩件数と帝 王切開手術割合の年次推移 - 昭和 59 年 平成 23 年 一. 平成 25 年 我が国の保健統計. http://www.mhlw. go.jp/toukei/list/dl/130-25_2.pdf [2015.11.12]

厚生学働省 (2015b)。「健やか親子 21 (第2次)」について 検 討会報告書. http://www.mhlw.go.jp/file/05-Shingikai11901000-Koyoukintoujidoukateikyoku-Soumuka/ 0000045654.pdf [2015.11.12]

國崎絢子, 渡辺久子, 平添まどか, 岩重希未恵 (2011)。 帝王切開分婏に対する思い・希望に関する調査一初 回帝王切開患者と前回帝王切開患者を比較して一. 日本看護学会論文集 母性看護, 41, 100-103.

Marut, J. S. \& Mercer, R. T. (1979). Comparison of primiparas' perceptions of vaginal and cesarean births. 
Nursing Research, 28(5), 260-266.

松井豊 (2010). 改訂新版 心理学論文の書き方 卒業論文や 修士論文を書くために。p.125，東京：河出書房新 社.

Mercer, R. T., Hackley, K. C., \& Bostrom, A. G. (1983). Relationship of psychosocial and perinatal variables to perception of childbirth. Nursing Research, 32(4), 202207.

壬生まゆみ，諸原祐三子，奈良美保子 (2002)。緊急帝王 切開産婦における出産体験の喪失を軽減するための 予期的指導の効果. 日本看護学会論文集 母性看護, $32, \quad 58-60$.

見目雅美，東野真弓 (2007)。緊急帝王切開術を体験した 裖婦の語りから振り返りの時期を考える。日本看護 学会論文集 母性看護，37，69-71.

三砂ちづる，嶋根卓也，野口真紀子，竹内正人，管原ます み，福島富士子，他 (2005)。変革につながるような 出産経験尺度 (TBE-scale) の開発 主体的出産経験 を定義する試み。臨床婦人科産科，59(9)，13031311.

三枝清美 (1999). 出産経験のとらえ方の尺度の検討. 母 性衛生，40(1), 138-143.

森恵美編 (2011)。系統看護学講座 専門分野 II 母性看護 2 母性看護学各論 (第11版)。p.391, 東京 : 医学書院.

村上宣寛 (2006)。心理尺度のつくり方. pp.35-71, 京 都 : 北大路書房.

中間みちよ, 山内京子 (2007). 緊急帝王切開術を受けた 母親の心理と看護援助の方向性. 看護学統合研究, 8 (2), 30-33.

岡田裕子, 白井やよい (1996). 帝王切開に至る過程と喪 失体験の関連一出産期待・母親役割期待の喪失を中 心に一. 日本看護学会集録 母性看護, 27, 115-118. 大林陽子, 石村由利子 (2010) : 緊急帝王切開後の裖婦の ストレスとその関連要因に関する研究 (第 1 報)。母
性衛生，51(1)，153-162.

Samko, M. R. \& Schoenfeld, L. S. (1975). Hypnotic susceptibility and the Lamaze childbirth experience. Am J Obstet Gynecol, 121(5), 631-636.

末村まい, 齋藤いずみ, 戸田まどか, 岩㠃三佳, 西海ひと み, 渡邊香織 (2011)。出産体験の「自己評価」および 「満足度」の尺度に関する文献研究。兵庫県母性衛生 学会雑誌, 20, 36-42.

鈴木のぞみ, 長谷川曜子, 中村恵里子, 東海林かち子, 河 村奈美子 (2011). 帝王切開産婦のバースプランの検 討一出産イメージやバースプランに対する意見より 一. 日本看護学会論文集 母性看護, 41, 108-111.

竹原健二，野口真貴子，嶋根卓也，三砂ちづる (2007). 出産体験尺度作成の試み。 民族衛生, 73(6), 211224.

竹内正人 (2014). 帝王切開のお産をケアしよう 帝王切開 最新の知識と取り巻く状況を概観する。助産雑誌, 68(2), 98-103.

常盤洋子, 今関節子 (2000), 出産体験自己評価尺度の作 成とその信頼性・妥当性の検討. 日本看護科学会誌, 20(1), 1-9.

常盤洋子, 國清恭子 (2006). 出産体験の自己評価に関 する研究の文献レビュー。 The Kitakanto Medical Journal, 56(4), 295-302.

山口さつき, 平山惠美子 (2011). 出産体験の自己評価に 影響を及ぼす要因。母性衛生，52(1)，160-167。

渡辺涼子, 三浦裕子, 城初子 (2008). 帝王切開術分娩決 定から術後までの産婦の心理 夫婦の望む帝王切開術 への看護を目指して。西尾市民病院紀要，19(1)，4451.

横手直美, 永田真弓, 宮里邦子 (2006). 緊急帝王切開で生 児を出産した女性の『母親としての再起』の認知プロ セスー産裖 1 週間における主観的体験の質的分析一. 母性衛生，46(4)，617-624. 